Relations industrielles

Industrial Relations

\title{
The Church and Economic Changes
}

\section{The Editors}

Volume 5, numéro 2, novembre 1949

URI : https://id.erudit.org/iderudit/1023284ar

DOI : https://doi.org/10.7202/1023284ar

Aller au sommaire du numéro

\section{Éditeur(s)}

Département des relations industrielles de l'Université Laval

ISSN

0034-379X (imprimé)

1703-8138 (numérique)

Découvrir la revue

Citer cet article

The Editors (1949). The Church and Economic Changes. Relations industrielles / Industrial Relations, 5(2), 11-11. https://doi.org/10.7202/1023284ar

Tous droits réservés (C Département des relations industrielles de l’Université Laval, 1949
Ce document est protégé par la loi sur le droit d'auteur. L’utilisation des services d'Érudit (y compris la reproduction) est assujettie à sa politique d'utilisation que vous pouvez consulter en ligne.

https://apropos.erudit.org/fr/usagers/politique-dutilisation/ 


\section{Industrial Relations Bulletin}

Volume 5, number 2

QUEBEC

November 1949

ROUND TABLE CONFERENCE

\section{THE CHURCH AND ECONOMIC CHANGES}

Recent events in the Province of Quebec have brought sharply to the attention of industrialists and businessmen the question of the social teaching of the Catholic Church.

The asbestos strike, the creation of the Sacerdotal Commission of Social Studies and certain of its attitudes, notably on the subject of the projected Labour Code and on the participation of workers in the life of the enterprise, and finally some declarations concerning capitalism, have aroused such interest that in certain circles the question has even been asked, «Is the Catholic Church going left ?».

Unquestionably the present year marks a decisive turning in labour relations in this Province and at the very moment when the Catholic Church is clarifying its point of view towards many thorny problems such as capitalism, the reform of enterprise, etc.

This combination of circumstances, added to the unaccustomed degree of restlessness which has characterized the Quebec industrial world in the last few months, has singularly contributed to confuse minds, so much so that many people well acquainted with these questions are finding difficulty in getting their bearings.

For all these reasons, and particularly to respond to the repeated requests of many English non-catholic businessmen, the Faculté des sciences sociales of l'Université Laval has decided to organize a conference, or Round Table, during the course of which competent persons will explain the social doctrine of the Catholic Church with reference to the crucial questions of the hour, and answer any questions on which further information may be sought. All the meetings will be in English.

The following experts, chosen from different circles, have been invited to speak: Father P.-E. Bolté, Professor in the University of Montreal, nember of the Sacerdotal Commission of Social Studies; Brother Justin, president of the Labour-Management School, Manhattan College, New York City; Murray G. Ballantyne, editor-in-chief of the great Catholic weekly, «The Ensign》, and Father Gerard Dion, Professor in Laval University, Director of the "Industrial Relations Bulletin 》 and member of the Sacerdotal Commision of Social Studies. The four subjects to be treated will be the following:

The Church and Property, the dignity of man, rights and duties of ownership, forms of ownership, capitalism, nationalizations, socialism and communism, distribution of wealth;

The Church AND ENTERPRise, nature of the enterprise, fair prices, fair wages, fair profits, working conditions, rights of proprietors, rights of workers, sharing in ownership, in profits and in management;

The Church AND the Right to Organize, the rights and duties of association, employer and employee associations, the aims of unions, collective agreements, Catholic Syndicates, the organization of industrial democracy;

PRIESTS AND Economics, the Church's right to intervene in economic matters, the interpretation of the Church's social teaching, role of the priest in unions, scope of action, education, promoting social organizations.

The meetings will be held at Kent House, near Montmorency Falls, on the 21st and the 22nd of November. The tranquil yet awe-inspiring surroundings will impress those taking part in the Conference and dispose them to understand the practical implications of the social teachings of the Catholic Church. 